\title{
The Influence of Oxygen, Glucose and Nitrate upon the Formation of Nitrate Reductase and the Respiratory System in Bacillus licheniformis
}

\author{
By J. A. SCHULP AND A. H. STOUTHAMER \\ Biologisch Laboratorium, Vrije Universiteit, De Boelelaan ro87, \\ Amsterdam-Buitenveldert, The Netherlands \\ (Accepted for publication I2 October 1970)

\begin{abstract}
SUMMARY
When a culture of Bacillus licheniformis was shifted from aerobic to anaerobic conditions, lysis occurred unless a fermentable carbon source or a system for nitrate respiration was present. Nitrate reductase was primarily induced by partial or complete anaerobiosis and partially repressed by glucose. The enzyme was repressed and inactivated by high oxygen concentrations. Respiration of bacteria grown anaerobically was 30 to $40 \%$ of that of bacteria grown aerobically. Glucose decreased respiration of other substrates in both aerobically and anaerobically grown organisms. No cytochrome $a_{1}$ was present after anaerobic growth. Cytochrome $c_{1}$ was repressed by glucose; under anaerobic conditions this repression was antagonized by nitrate.
\end{abstract}

\section{INTRODUCTION}

Most of the work in the regulation of nitrate reductase has been done with coliform bacteria, in which it is induced by anaerobiosis in the presence of nitrate. The enzyme is repressed, inhibited and inactivated by oxygen (Pichinoty, I965; Van't Riet, Stouthamer \& Planta, 1968; De Groot \& Stouthamer, 1970a)

Hackenthal (1966) found parallel induction of nitrate and nitrite reductase by nitrate, nitrite and some other monovalent anions in Bacillus cereus. In B. stearothermophilis nitrate reductase was induced by nitrate and repressed and inactivated by oxygen. When cells were adapted to nitrate, oxygen respiration decreased by 50 to $70 \%$; the main change in the cytochrome spectrum was the disappearance of cytochrome $a_{3}$ (Downey, I966; Downey \& Nuner, I967; Downey \& Kiszkiss, 1969; Downey, Kiszkiss \& Nuner, 1969).

The Bacillus species in which nitrate reductase formation has been studied so far are obligate organisms. This paper describes a study of the regulation of nitrate reductase formation and of the influence of nitrate, glucose and oxygen on respiratory activity and cytochrome content in the facultative organism Bacillus licheniformis.

\section{METHODS}

Organism: Bacillus licheniformis $\mathbf{2} 244$ (originally designated $B$. licheniformis 430) was obtained from Dr J. W. Woldendorp, Agricultural University, Wageningen, The Netherlands. It was maintained on slopes of Oxoid brain heart infusion agar and stored at $4^{\circ}$. 
Media. NBY medium contained Oxoid nutrient broth no. $2,8 \mathrm{~g} . / 1$, and Oxoid yeast extract, $3 \mathrm{~g}$./l. NBYG was made by adding glucose ( $5 \mathrm{~g} . / 1$.); $\mathrm{NBYGNO}_{3}$ by adding glucose (5 g./1.) and $\mathrm{KNO}_{3}\left(2 \mathrm{~g}\right.$./1.); and $\mathrm{NBYNO}_{3}$ by adding $\mathrm{KNO}_{3}$ (10 g./1.). Glucose and nitrate were added from sterile stock solutions. The $\mathrm{pH}$ of all media was $7 \cdot 0$.

Cultural conditions. Bacteria were grown at $37^{\circ}$ in a New Brunswick MicroFerm Laboratory fermentor in a 71 . jar containing 31 . of medium either with vigorous aeration (Io l. air/min., agitation $650 \mathrm{rev} . / \mathrm{min}$.), with weak aeration (2 l. air $/ \mathrm{min}$., agitation $200 \mathrm{rev} . / \mathrm{min}$.) or anaerobically (nitrogen, agitation $100 \mathrm{rev} . / \mathrm{min}$.). The medium in the jar was inoculated with $2 \times 100 \mathrm{ml}$. of culture in NBY, shaken overnight at $250 \mathrm{rev} . / \mathrm{min}$. at $37^{\circ}$ in a $500 \mathrm{ml}$. bottle. If required, the $\mathrm{pH}$ of the medium was maintained at $\mathrm{pH} 7$ by a New Brunswick automatic $\mathrm{pH}$ controller using $0.5 \mathrm{~N}-\mathrm{NaOH}$. Dissolved oxygen concentration was measured with a New Brunswick oxygen electrode and is expressed as percentage of the dissolved oxygen concentration in the oxygensaturated medium. Bacterial density was determined by measuring the extinction at $660 \mathrm{~nm} .\left(E_{660}\right)$ in a Unicam SP 600 spectrophotometer.

Harvesting of bacteria and preparation of cell-free extracts. Bacteria were harvested by centrifugation in an MSE I 8 high speed centrifuge at $10,000 \mathrm{~g}$ at $2^{\circ}$ for $15 \mathrm{~min}$. For cell-free extracts, they were washed twice with cold phosphate buffer, $0.065 \mathrm{M}, \mathrm{pH} 7$, resuspended in this buffer and sonicated in an MSE ultrasonic disintegrator, $60 \mathrm{~W}$, $20 \mathrm{kc}$. $/ \mathrm{sec}$. for $10 \mathrm{~min}$. at $0^{\circ}$. Cellular debris was not removed, as this caused fluctuations in nitrate reductase activity.

Suspensions in phosphate buffer lysed rapidly at $37^{\circ}$ and failed to respire. Lysis was prevented by adding $\mathrm{MgSO}_{4} \cdot 7 \mathrm{H}_{2} \mathrm{O}$ (10 \%,w/v). Bacterial suspensions were therefore washed and resuspended in $\mathrm{MgSO}_{4} \cdot 7 \mathrm{H}_{2} \mathrm{O}$ (I00 g./1.), tris ( $1 \cdot 2 \mathrm{I}$ g./l.), $\mathrm{KCl}(2 \cdot 47 \mathrm{~g}$./1.), adjusted to $\mathrm{pH}_{7}$ with $\mathrm{HCl}$. Throughout harvesting, chloramphenicol $(30 \mu \mathrm{g} . / \mathrm{ml}$.) was present.

Measurement of acid formation. Cultures were grown anaerobically in NBYG or $\mathrm{NBYGNO}_{3}$ to $E_{660} \approx \mathrm{I} \cdot 4$. Four hundred $\mathrm{ml}$. of culture was chilled by addition of ice. The bacteria were harvested by centrifugation and resuspended in $200 \mathrm{ml}$. of fresh cold NBYG medium with chloramphenicol (30 $\mu \mathrm{g} . / \mathrm{ml}$.). Samples $(50 \mathrm{ml}$.) in a beaker were gently stirred and bubbled with nitrogen in a $37^{\circ}$ water bath. The $\mathrm{pH}$ was measured continuously with a Philips pH meter model PR 9403/0I and at 2 min. intervals adjusted to $\mathrm{pH} 7$ with $\mathrm{NaOH}(c .0 . \mathrm{I} \mathrm{N})$ previously titrated with $0 . \mathrm{I} \mathrm{N}$-oxalic acid. At zero time $0.5 \mathrm{ml}$. of distilled water or $20 \% \mathrm{KNO}_{3}$ solution was added. Samples $(0.5 \mathrm{ml}$.) were taken for glucose determinations at $5 \mathrm{~min}$. intervals.

Cytochromes. Cytochromes were measured in dithionite-reduced suspensions using a Unicam SP 800 spectrophotometer. Cytochrome $c_{1}$ content was expressed as the difference in extinction between the peak at $552 \mathrm{~nm}$. and the line connecting 540 and $570 \mathrm{~nm}$.; cytochrome $a_{1}$ content as the difference in extinction between the peak at $595 \mathrm{~nm}$. and the line connecting 580 and $610 \mathrm{~nm}$. Specific cytochrome content was expressed as $E_{552}$ or $E_{595} /$ IO $\mathrm{mg}$. of protein.

Other assays. Oxygen uptake by whole bacteria was measured by standard Warburg techniques.

Glucose content of the medium was determined with the glucose oxidase (Boehringer, Mannheim, Germany).

Nitrite content of the medium was assayed as described by Van't Riet, Stouthamer \& Planta (I968). 
Nitrate reductase activity was measured according to Lowe \& Evans (1964); the assay mixtures were incubated for $15 \mathrm{~min}$. at $37^{\circ}$.

Protein was estimated according to Lowry, Rosebrough, Farr \& Randall (I95I).

\section{RESULTS}

Effect of anaerobiosis, induction of nitrate reductase and lysis

In vigorously aerated cultures, no nitrate reductase could be demonstrated as long as the cell density was not too high. When a $\mathrm{NBYNO}_{3}$ culture grown with vigorous aeration was shifted to anaerobic conditions, rapid lysis occurs (Fig. I) and no nitrite was formed.

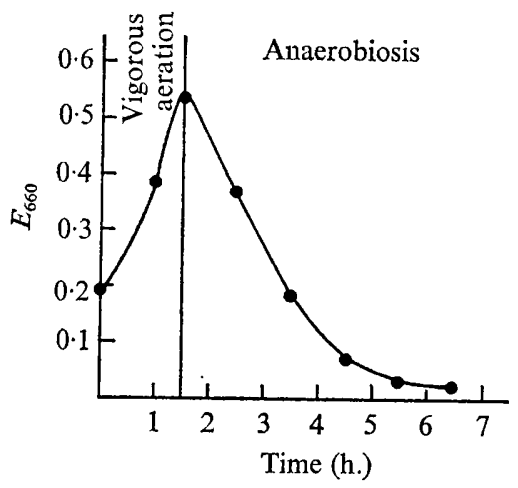

Fig. I

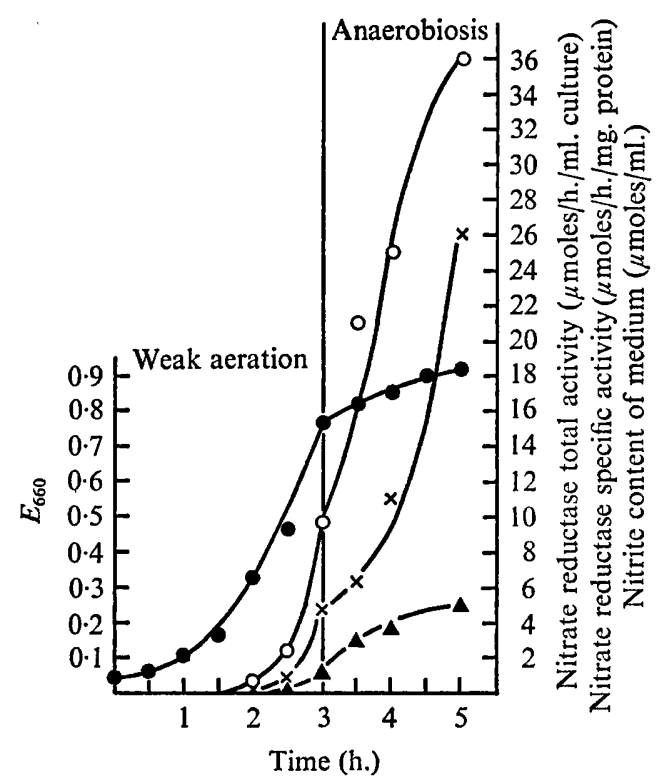

Fig. 2

Fig. I. Lysis of Bacillus licheniformis $\mathrm{S} 244$ in $\mathrm{NBYNO}_{3}$ medium after a shift from vigorous aeration to anaerobiosis.

Fig. 2. Growth, nitrite formation and nitrate reductase synthesis of Bacillus licheniformis $\mathrm{s} 244$ in $\mathrm{NBYNO}_{3}$ medium during weak aeration, followed by a shift to anaerobiosis. $\bullet, E_{660}$; $\mathrm{O}$, nitrate reductase specific activity; $\boldsymbol{\Delta}$, nitrate reductase total activity; $\times$, nitrite content of medium.

When grown with weak aeration in $\mathrm{NBYNO}_{3}$, the oxygen consumption by the bacteria soon exceeded the oxygen supply and the oxygen tension in the medium was reduced. Nitrate reductase was induced and nitrite was produced. During this period, oxygen and nitrate respiration were occurring simultaneously, and change to anaerobic conditions did not cause lysis until the nitrate was exhausted (Fig. 2).

In glucose-containing media, shifts from vigorous aeration to anaerobic conditions never caused lysis, but acid was produced immediately. In cultures without $\mathrm{pH}$ regulation, growth stopped when $\mathrm{pH} 5.7$ was reached (Fig. $3 a$ ). The $\mathrm{pH}$ was regulated in all further experiments in glucose-containing media. Nitrate reductase was formed under anaerobic conditions in NBYG, in spite of the absence of nitrate (Fig. $3 a$ ). 
Addition of nitrate caused a further $2 \cdot 5$-fold increase in specific activity (Fig. $3 b$ ). Specific activity in $\mathrm{NBYNO}_{3}$ was considerably higher than in glucose-containing media: glucose repressed nitrate reductase. More nitrite was formed in $\mathrm{NBYNO}_{3}$ than in $\mathrm{NBYGNO}_{3}$, in spite of the greater total nitrate reductase activity in the latter medium. Apparently, in the presence of glucose the transfer of electrons to the nitrate reductase was less effective.

(a) NBYG

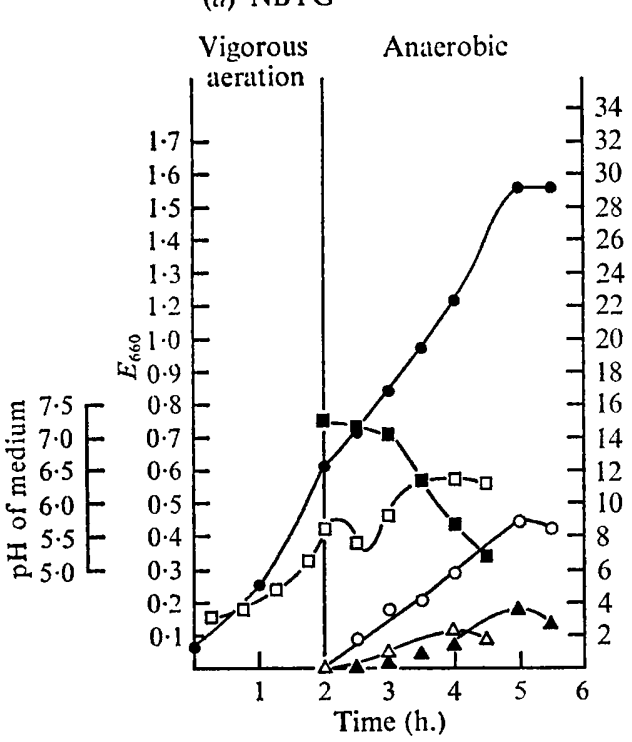

(b) $\mathrm{NBYGNO}_{3}$

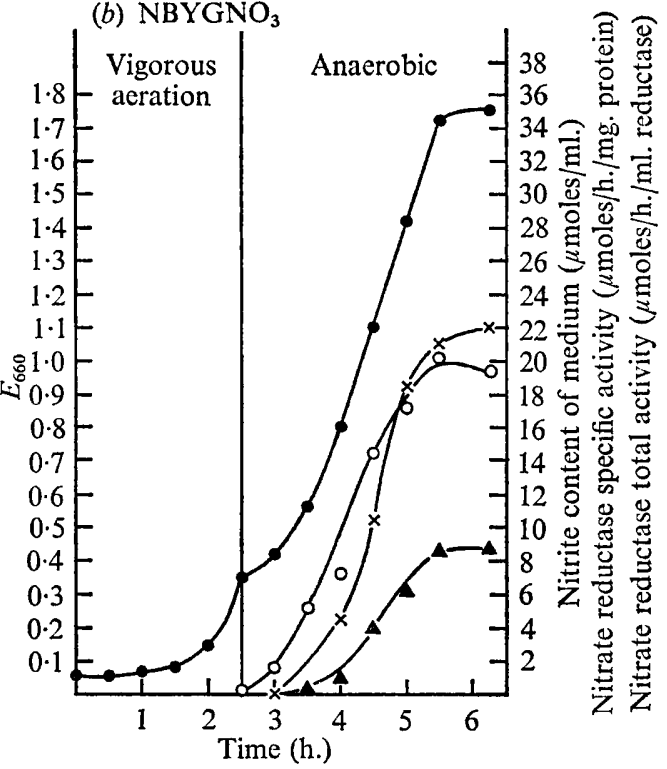

Fig. 3. Growth and nitrate reductase formation of $B$. licheniformis $\mathbf{S} 244$ in (a) NBYG and (b) $\mathrm{NBYGNO}_{3}$ media after a shift from vigorous aeration to anaerobiosis, with and without $\mathrm{pH}$ control. With pH control: $\bullet, E_{660} ; O$, nitrate reductase specific activity; $\boldsymbol{\Lambda}$, nitrate reductase total activity; $\times$, nitrite content of medium. Without $\mathrm{pH}$ control (applies to (a) only): $\square$, $E_{660} ; \triangle$, nitrate reductase specific activity; $\boldsymbol{\varpi}, \mathrm{pH}$ of the medium.

Effect of aeration. Bacillus licheniformis was grown in NBY, $\mathrm{NBYNO}_{3}, \mathrm{NBYG}$ and $\mathrm{NBYGNO}_{3}$ media with weak aeration, and the dissolved oxygen content, nitrate reductase and nitrite formation were followed. Nitrate reductase formation in glucosefree and glucose-containing media started at 20 and $0 \%$ oxygen respectively (Fig. $4 a, b)$. In NBY and $\mathrm{NBYNO}_{3}$ nitrate reductase was produced at the same rate; the same applies to NBYG and $\mathrm{NBYGNO}_{3}$. Also, in $\mathrm{NBYNO}_{3}$ and $\mathrm{NBYGNO}_{3}$, nitrite formation started at 20 and $0 \%$ oxygen respectively (Fig. 4). When an oxygen concentration of $20 \%$ was reached in NBY and $\mathrm{NBYNO}_{3}$, the oxygen concentration did not decrease any further, and the growth rates dropped (Fig. $4 a$ ).

Inactivation of nitrate reductase by aeration. When an anaerobic $\mathrm{NBYGNO}_{3}$ culture was aerated vigorously, the specific nitrate reductase activity dropped, but the total activity remained constant, and the nitrite content of the medium still increased. Therefore, in order to study inactivation of nitrate reductase by aeration, growth and oxygen consumption have to be decreased by suspending the bacteria in a buffer with chloramphenicol and without substrate (Fig. 5). The aerated suspension showed inactivation of nitrate reductase, whereas the nitrate reductase activity in the nonaerated suspension remained constant. 


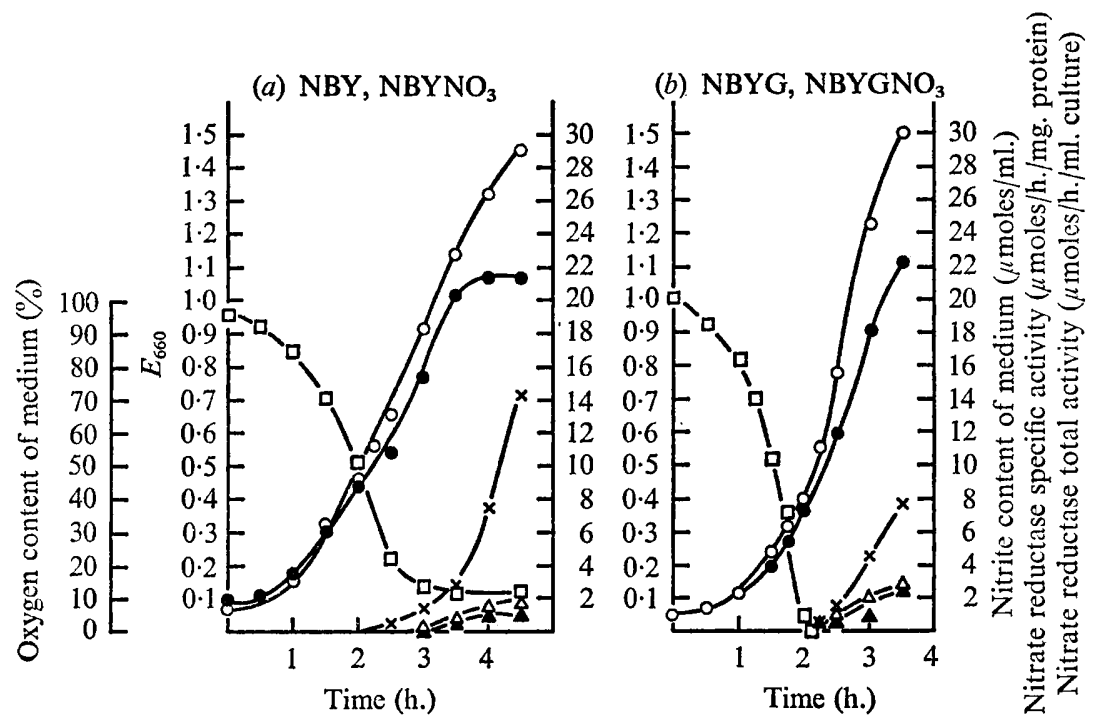

Fig. 4. Growth, oxygen consumption, nitrate reductase and nitrite formation in various media with weak aeration. Closed symbols: NBY, NBYG. Open symbols: $\mathrm{NBYNO}_{3}$, $\mathrm{NBYGNO}_{3} . \mathrm{O}, E_{660} ; \triangle \Delta$, nitrate reductase; $\square$, oxygen concentration (for all media); $\times$, nitrite content of medium ( $\mathrm{NBYNO}_{3}$ and $\mathrm{NBYGNO}_{3}$ only).

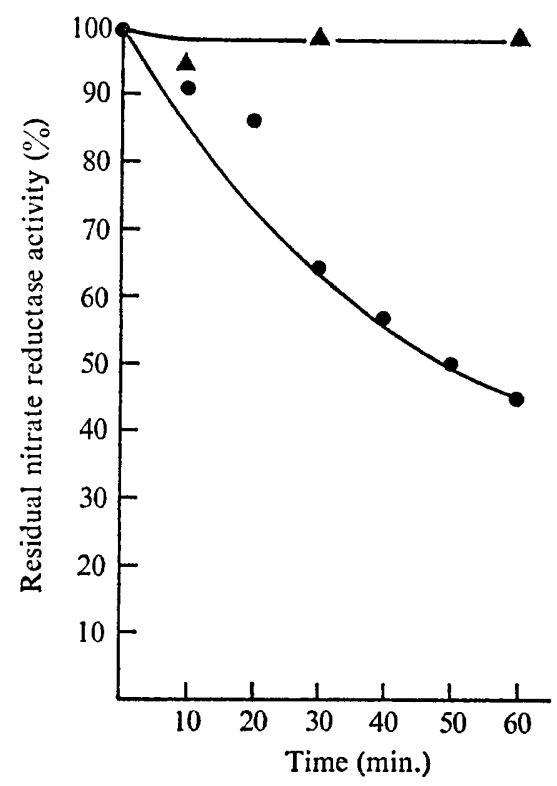

Fig. 5. Effect of aeration upon nitrate reductase in cells grown anaerobically in $\mathrm{NBYGNO}_{3}$ to $E_{660}=\mathrm{I} \cdot 5$. Cells were washed and resuspended in $\mathrm{Mg}$-tris- $\mathrm{KCl}$ medium to $E_{660}=\mathrm{I} \cdot 5.50 \mathrm{ml}$. was shaken in a $500 \mathrm{ml}$. flask at $37^{\circ}$ in a water bath shaker at a speed of 250 strokes $/ \mathrm{min}$. (O). $50 \mathrm{ml}$. was left static at $37^{\circ}$ in a $50 \mathrm{ml}$. flask (A). At $5 \mathrm{~min}$. intervals, $5 \mathrm{ml}$. samples were removed for determination of the residual nitrate reductase activity. During harvesting, washing and the inactivation experiment, $30 \mu \mathrm{g}$. of chloramphenicol $/ \mathrm{ml}$. was present. 
Changes in the respiratory system, concomitant with anaerobiosis and nitrate respiration. Table I shows oxygen uptake by suspensions of washed bacteria, grown under various conditions. After anaerobic growth in $\mathrm{NBYNO}_{3}$, respiration with all substrates was reduced to 30 to $40 \%$ of the aerobic level, as was glucose respiration in glucose-containing media. The presence of glucose reduced respiration of all substrates except glucose and abolished that of acetate and citrate.

\section{Table I. Effect of growth conditions on oxygen uptake}

Averages of two or three experiments are given. Correction has been made for endogenous oxygen uptake.

Oxygen uptake ( $\mu$ moles $\mathrm{O}_{2} / \mathrm{mg}$. protein/h.)

\begin{tabular}{|c|c|c|c|c|c|c|}
\hline \multirow[b]{2}{*}{ Substrate } & \multicolumn{3}{|c|}{ Aerobic } & \multicolumn{3}{|c|}{ Anaerobic } \\
\hline & $\begin{array}{l}\mathrm{NBY} \text { or } \\
\mathrm{NBYNO}_{3}\end{array}$ & $\mathrm{NBYGNO}_{3}$ & NBYG & $\mathrm{NBYNO}_{3}$ & $\mathrm{NBYGNO}_{3}$ & NBYG \\
\hline Glucose & I 2.08 & 13.96 & $10 \cdot 33$ & $3 \cdot 7 \mathrm{I}$ & $5 \cdot 94$ & $3 \cdot 66$ \\
\hline Pyruvate & 10.52 & $5 \cdot 22$ & $3 \cdot 42$ & $3 \cdot 25$ & $2 \cdot 13$ & $2 \cdot 53$ \\
\hline Acetate & $10 \cdot 79$ & 0 & 0 & 3.59 & 0 & 0 \\
\hline Citrate & $2 \cdot 16$ & 0 & 0 & 0.91 & 0 & 0 \\
\hline Succinate & 13.09 & $2 \cdot 01$ & 0.70 & $3 \cdot 57$ & 0.44 & 0 \\
\hline
\end{tabular}

Table 2. Effect of growth conditions on cytochrome content

\begin{tabular}{|c|c|c|c|c|c|c|}
\hline \multirow[b]{2}{*}{ Medium } & \multicolumn{3}{|c|}{$\begin{array}{c}\text { Cytochrome } c_{1} \\
E_{552} / \text { Io mg. protein }\end{array}$} & \multicolumn{3}{|c|}{$\begin{array}{c}\text { Cytochrome } a_{1} \\
E_{595} / 10 \mathrm{mg} \text {. protein }\end{array}$} \\
\hline & $\begin{array}{l}\text { Vigorous } \\
\text { aeration }\end{array}$ & $\begin{array}{l}\text { Weak } \\
\text { aeration }\end{array}$ & Anaerobic & $\begin{array}{l}\text { Vigorous } \\
\text { aeration }\end{array}$ & $\begin{array}{c}\text { Weak } \\
\text { aeration }\end{array}$ & $\begin{array}{l}\text { Anaer- } \\
\text { obic }\end{array}$ \\
\hline NBY & 0.210 & 0.187 & - & 0.058 & 0.051 & - \\
\hline $\mathrm{NBYNO}_{3}$ & 0.196 & 0.143 & 0.189 & 0.064 & 0.061 & 0 \\
\hline NBYG & 0.046 & 0.059 & 0.056 & $0.08 \mathrm{I}$ & 0.011 & 0 \\
\hline $\mathrm{NBYGNO}_{3}$ & 0.042 & 0.047 & 0.110 & 0.083 & 0.015 & 0 \\
\hline
\end{tabular}

Table 3. Effect of nitrate in growth and test media upon rate of acid formation and glucose consumption

\begin{tabular}{|c|c|c|c|c|}
\hline \multirow[b]{2}{*}{ Cultivation medium } & \multicolumn{2}{|c|}{$\begin{array}{l}\text { Acid formation ( } \mu \text { moles } / \mathrm{mg} \text {. } \\
\text { protein } / \mathrm{h} .) \text { in }\end{array}$} & \multicolumn{2}{|c|}{$\begin{array}{l}\text { Glucose consumption ( } \mu \text { moles } / \mathrm{mg} \\
\text { protein/h.) in }\end{array}$} \\
\hline & NBYG & $\mathrm{NBYGNO}_{3}$ & NBYG & $\mathrm{NBYGNO}_{3}$ \\
\hline NBYG & I $2 \cdot 70$ & $8 \cdot 4$ & 5.04 & $5 \cdot 60$ \\
\hline $\mathrm{NBYGNO}_{3}$ & $\mathrm{II} \cdot 78$ & $7 \cdot 3$ & $5 \cdot 70$ & $5 \cdot 30$ \\
\hline
\end{tabular}

The cytochrome contents of bacteria grown under different conditions are given in Table 2. Although some $b$-type cytochrome was present, this could not be determined quantitatively from our spectra. Glucose strongly repressed cytochrome $c_{1}$ formation; under anaerobic conditions, this repression was somewhat released by nitrate.

After growth with vigorous aeration with or without glucose, cytochrome $a_{1}$ was present. In bacteria grown anaerobically it was completely absent. The amount of cytochrome $a_{1}$ in bacteria grown without glucose was the same whether they had been vigorously or weakly aerated. In cultures grown in glucose-containing media with weak aeration, however, considerably less cytochrome $a_{1}$ was found. This could be 
explained by the fact that in glucose-free media with weak aeration $20 \%$ of the dissolved oxygen is left, and in glucose-containing media nothing.

Effect of nitrate upon the rate of acid formation and glucose breakdown. The rates of acid formation and glucose consumption were measured in NBY and $\mathrm{NBYGNO}_{3}$, after cultivation in these media, as described under Methods. Nitrate decreased acid formation by $40 \%$, but did not influence the rate of glucose breakdown (Table 3).

\section{DISCUSSION}

When aeration of cultures of Bacillus subtilis is interrupted, rapid lysis ('anaerobic lysis') occurs (Nomura, I955). Similarly, lysis of B. subtilis during aerobic growth is observed after exhaustion of the energy source in the medium (Monod, I942; Hadjipetrou \& Stouthamer, I963; Baillie \& Holms, I968). In this organism, lysis occurs when the generation of ATP is interrupted. Bacillus licheniformis behaves similarly in that anaerobic lysis can be prevented only by the presence of the nitrate-reducing system or a fermentable carbon source. Bacillus subtilis and B. licheniformis appear to be subject to autolysis in the absence of the continued synthesis of cell wall substance (Shockman et al. 1961), for which ATP is required. This autolytic activity interferes with the preparation of washed suspensions; $10 \% \mathrm{MgSO}_{4} \cdot{ }_{7} \mathrm{H}_{2} \mathrm{O}$ protected cells of $B$. licheniformis. In this medium the bacteria retained their normal rod-like shape, perhaps because the autolytic enzymes were inhibited by the high concentration of $\mathrm{Mg}^{2+}$ ions.

The most striking feature of the regulation of nitrate reductase formation in Bacillus licheniformis is the induction by anaerobiosis, even in absence of nitrate. In Escherichia coli (Showe \& De Moss, I968), Aerobacter aerogenes (Van't Riet et al. I968), Proteus mirabilis (De Groot \& Stouthamer, 1970a) and Haemophilus parainfluenzae (Sinclair $\&$ White, 1970) nitrate reductase activity is low or absent during anaerobiosis in the absence of nitrate. Showe \& De Moss (1968) have suggested that the formation of nitrate reductase in $E$. coli is regulated by two repressors, one of which is sensitive to nitrate, and a second which is sensitive to the intracellular redox potential. The presence of two repressors for the regulation of nitrate reductase formation has also been postulated for $H$. parainfluenzae (Sinclair \& White, 1970) and for $P$. mirabilis (De Groot \& Stouthamer, I970a). In B. licheniformis the intracellular redox potential is of prime importance in the regulation of nitrate reductase formation, and there is no evidence for regulation by nitrate.

Azoulay, Puig \& Couchaud-Beaumont (1969) have shown that redox enzymes in Escherichia coli chlorate-resistant mutants cannot be complexed in active membranebound form. Similarly, Azoulay, Puig \& Martins Rosado de Sousa (I969) proposed that complexing of redox enzymes is also impossible during aerobic growth. De Groot \& Stouthamer ( $1970 \mathrm{~b}$ ) have observed that in Proteus mirabilis the formation of redox enzymes is repressed when there is no electron flow to these enzymes, and suggested that such enzymes cannot be complexed in active membrane-bound form with other electron transport components without electron flow. Induction and glucose repression of nitrate reductase in Bacillus licheniformis can be explained in a similar way. With weak aeration, the oxygen supply is limiting and electrons can flow to nitrate reductase. In glucose-containing media there is hardly any electron flow to nitrate reductase from other substrates, because their oxidation is inhibited (Table I). In 
medium with glucose, active fermentation of glucose occurs and consequently the total electron flow to nitrate reductase is small. The possibility that glucose acts by catabolite repression cannot be ruled out.

Inactivation of nitrate reductase has been observed in Proteus mirabilis only when the electron flow is withdrawn from the enzyme (De Groot \& Stouthamer, 1970 a). In Bacillus licheniformis nitrate reductase is less easily inactivated and occurs only with vigorous aeration in the absence of a substrate that can be respired (Fig. 5). In a complete medium there is repression, no inactivation. It seems that inactivation requires complete withdrawal of the electron flow, whereas for repression a partial withdrawal is sufficient.

The effect of glucose inhibiting oxidation of other substrates by Bacillus licheniformis has also been shown in Staphylococcus aureus (Strasters \& Winkler, 1963). This is surprising, as the effect of glucose upon the citric acid cycle enzymes in the closely related species $B$. subtilis and even in another strain of $B$. licheniformis is completely different. In these organisms the enzymes of the first part of the citric acid cycle are partially repressed by glucose and almost completely repressed by a mixture of glucose and glutamate. The enzymes of the second part of the citric acid cycle are not affected (Flechtner \& Hanson, 1969). Repression of cytochrome $c$ by glucose is also known from S. aureus (Strasters \& Winkler, I963), and from Salmonella typhimurium (Richmond \& Maaløe, 1962).

The influence of anaerobiosis upon respiration has recently been reviewed by Wimpenny (1969). Aeration of cells grown anaerobically generally leads to a three- or four fold increase of overall respiratory activity. Thus Bacillus licheniformis fits well into the general pattern.

Increase of cytochrome- $c$ content and complete disappearance of $a$-type cytochromes during nitrate respiration has been reported for Micrococcus denitrificans (Scholes \& Smith, 1968) and for Bacillus stearothermophilus (Downey \& Kiszkiss, I969). Downey \& Kiszkiss (I969) suppose that disappearance of $a$-type cytochromes is a common feature of denitrifying bacteria, and that it is caused by active nitrate respiration. When $B$. licheniformis is cultivated anaerobically in NBYG medium, however, nitrate reductase is formed, but no active nitrate respiration occurs because of the absence of nitrate. So we conclude that in $B$. licheniformis disappearance of $a$-type cytochrome is merely caused by anaerobiosis.

The present investigations have been sponsored by the Netherlands Foundation for Chemical Research (S.O.N.) and the Netherlands Organization for the Advancement of Pure Research (Z.W.O.).

\section{REFERENCES}

Azoulay, E., Puig, J. \& Couchaud-Beaumont, P. (1969). Etudes des mutants chlorate-résistents chez Escherichia coli $\mathrm{K}$ I2. I. Réconstitution in vitro de l'activité nitrate-réductase particulaire chez Escherichia coli $\mathrm{K}$ I2. Biochimica et biophysica acta 17, 238-252.

Azoulay, E., Puig, J. \& Martins Rosado de Sousa, M. L. (1969). Régulation de la synthèse de la nitrate-réductase chez Escherichia coli K I2. Annales de l'Institut Pasteur, Paris 117, 475-485.

BAILLIE, R. D. \& Holms, H. W. (1968). Loss of viability and respiration of Bacillus subtilis grown in peptone medium supplemented with glucose. Biochimica et biophysica acta 170, 442-445.

De Groot, G. N. \& Stouthamer, A. H. (I970a). Regulation of reductase formation in Proteus mirabilis. II. Influence of growth with azide and of heme deficiency on nitrate reductase formation. Biochimica et biophysica acta 208, I14-427. 
De Groot, G. N. \& Stouthamer, A. H. (1970 $b$ ). Regulation of reductase formation in Proteus mirabilis. III. Influence of oxygen, nitrate and azide on thiosulphate reductase and tetrathionate reductase. Archiv für Mikrobiologie. 74, 340-349.

DowNEY, R. J. (1966). Nitrate reductase and respiratory adaptation in Bacillus stearothermophilus. Journal of Bacteriology 91, 634-64I.

DowneY, R. J. \& Kiszxiss, D. F. (1969). Oxygen and nitrate induced modification of the electron transfer system of Bacillus stearothermophilus. Microbios 2, I45-I 53.

DOWNEY, R. J., KISZKISS, D. F. \& NUNER, J. H. (1969). Influence of oxygen on development of nitrate respiration in Bacillus stearothermophilus. Journal of Bacteriology 98, 1056-1062.

DOWNEY, R. J. \& NUNER, J. H. (1967). Induction of nitrate reductase under conditions of nitrogen depletion. Life Sciences 6, 855-86I.

FlechtneR, V. R. \& Hanson, R. S. (1969). Coarse and fine control of citrate synthase from Bacillus subtilis. Biochimica et biophysica acta 184, 252-262.

HACKENTHAL, E. (I966). Die parallele Induktion von Nitratreduktase bei Bacillus cereus durch verschiedene Anionen. Biochemical Pharmacology I5, I I 19 -I I 26.

Hadipetrou, L. P. \& Stouthamer, A. H. (1963). Autolysis of Bacillus subtilis by glucose depletion. Antonie van Leeuwenhoek 29, 256-260.

Lowe, R. H. \& Evans, H. J. (1964). Preparation and some properties of a soluble nitrate reductase from Rhizobium japonicum. Biochimica et biophysica acta 85, 377-389.

Lowry, O. H., Rosebrough, N. J., FarR, A. L. \& Randall, R. J. (I95I). Protein measurement with the Folin phenol reagent. Journal of Biological Chemistry 193, 265-275.

Monod, J. (1942). Recherches sur la Croissance des Cultures Bacteriènnes. Paris: Herman and Cie.

Nomura, M. (1955). Studies on the autolytic phenomenon of Bacillus subtilis. I. The anaerobic lysis of Bacillus subtilis. II. Discoveries of the killing factor and autolysis in the lysate and induced lysis of Bacillus subtilis with ultraviolet light. Journal of the Agricultural Chemical Society of Japan 29, $674-682$.

Pichinoty, F. (1965). L'effet d'oxygène de la biosynthèse des enzymes d'oxydoréduction bactériens. Centre National de Recherche Scientifique Symposia 124, 507-522.

Richmond, M. H. \& MaAløE, O. (1962). The rate of growth of Salmonella typhimurium with individual carbon sources, related to glucose metabolism or the Krebs cycle. Journal of General Microbiology 27, 285-297.

SCHOLES, P. B. \& SMITH, L. (1968). Composition and properties of the membrane-bound respiratory chain system of Micrococcus denitrificans. Biochimica et biophysica acta 153, 363-375.

Shockman, G. D., Conover, M. J., Kolb, J. J., Phillips, P. M., Riley, L. S. \& Toennies, G. (196i). Lysis of Streptococcus faecalis. Journal of Bacteriology 83, 106-III.

SHOWE, M. K. \& DE Moss, J. A. (1968). Localization and regulation of nitrate reductase in Escherichia coli. Journal of Bacteriology 95, I305-1313.

SinCLAIR, P. R. \& WHITE, D. C. (1970). Effect of nitrate, fumarate and oxygen on the formation of membrane-bound electron transport system of Haemophilus parainfluenzae. Journal of Bacterio$\log y$ 101, 365-372.

Strasters, K. C. \& WinkLer, K. C. (1963). Carbohydrate metabolism of Staphylococcus aureus. Journal of General Microbiology 33, 21 3-229.

Van't Riet, J., Stouthamer, A. H. \& Planta, R. J. (1968). Regulation of nitrate assimilation and nitrate respiration in Aerobacter aerogenes. Journal of Bacteriology 96, 1455-1464.

WIMPENNY, J. W. T. (1969). Oxygen and carbon dioxide as regulators of microbial growth and metabolism. Symposia of the Society for General Microbiology 19, 16I-197. 